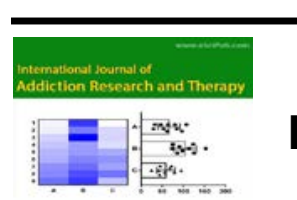

International Journal of Addiction Research and Therapy

(ISSN:2637-8795)

\title{
IMPACT OF MENTAL HEALTH AND BEHAVIORAL DISORDER DUE TO THE USE OF ALCOHOL IN THE PERNAMBUCO POPULATION: AN ANALYSIS FROM NATIONAL HEALTH INDICATORS
}

Wirley Matias Alves Martins Duarte ${ }^{1 *}$; Lívia Lócio Rosado de Oliveira²; William Barros Agrelli Girão $^{3}$; Mateus Cotias Filizola ; Eduardo Tomilheiro de Farias ${ }^{5}$; Edmundo de Oliveira Gaudêncio ${ }^{6}$ ${ }^{1}$ Estudante do Curso de Medicina da Universidade UFCG; ${ }^{2}$ Estudante do Curso de Medicina da Universidade Pernambucana de Saúde, ${ }^{3,4,5}$ Estudante do Curso de Medicina da Universidade Federal de Pernambuco - UFPE; ${ }^{6}$ Professor Associado II da Universidade Federal de Campina Grande.

\section{ABSTRACT}

Introduction: Alcohol abuse does not characterize a state of character or weakness, it is a physical and psychological dependence that manipulates a dependent's conduct and interposes between the individual, a family and other social relationships. There are 3.3 million deaths per year, due to harmful use of alcohol, and ranks as the third disease that kills the most in the world. In Brazil, it is estimated that $4.2 \%$ of the population most likely to be abused or addicted, alarming compared to the world average. Objective: To analyze the prevalence data in new cases of mental and behavioral disorders due to alcohol use, from 2014 to 2018 by sample of municipalities in the state of Pernambuco with more than 100 new cases in the period. Methodology: This is a study in secondary databases, conducted from the Brazilian Basic Data indicators, an integral tool of the health information system, using quantitative analysis of variables. Results: There was a reduction of $8 \%$ in new cases in 2018 when compared to 2014 . The municipality of Vitória de Santo Antão had a greater relative reduction of new cases in the period, from 82 in 2014 to 5 new cases in 2018. Paulista presented 559 fewer new cases when comparing 2018 and 2014, this being the largest absolute reduction among the municipalities. Men were 18 times more dependent than women, and the population aged 30 to 59 years had 4.6 times more new cases than the other age groups. Discussion: It is generally observed that there were significant reductions in the number of new cases when evaluating all municipalities in Pernambuco. This may be associated with the expansion of preventive public health education policies aimed at raising awareness of the use and abuse of the population and the role of multidisciplinary teams towards the dependent patient, with a view to the integral attention of the dependent and his personal relationships, fundamental to maintaining mental health. Conclusion: The data analysis showed that despite the reduction of hospitalizations related to alcohol abuse, there is still a need for new public policies in relation to these patients, focusing on the male gender and the potentially active age population, since the reduction of the incidence of these patients. cases over the years and reflects a direct reduction in mental and behavioral disorders in the state of Pernambuco population.
Keywords: Epidemiology; Alcohol Consumption; Mental Health.

*Correspondence to Author:

Wirley Matias Alves Martins Duarte

Estudante do Curso de Medicina da Universidade UFCG

How to cite this article:

Wirley Matias Alves Martins Duarte; Lívia Lócio Rosado de Oliveira; William Barros Agrelli Girão; Mateus Cotias Filizola4; Eduardo Tomilheiro de Farias; Edmundo de Oliveira Gaudêncio.IMPACT OF MENTAL HEALTH AND BEHAVIORAL DISORDER DUE TO THE USE OF ALCOHOL IN THE PERNAMBUCO POPULATION: AN ANALYSIS FROM NATIONAL HEALTH INDICATORS .International Journal of Addiction Research and Therapy, 2020, 3:15

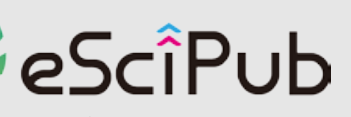

eSciPub LLC, Houston, TX USA. Website: https://escipub.com/ 